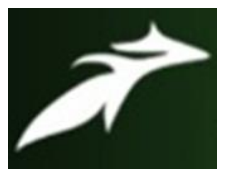

Bankitbok Kharphuli et al, International Journal of Advances in Agricultural Science and Technology,

Vol.8 Issue.8, August-2021, pg. 183-188

ISSN: 2348-1358

Impact Factor: 6.057

NAAS Rating: 3.77

\title{
Knowledge of the Ginger Growers toward Improved Cultivation Technology in Ri-Bhoi District of Meghalaya
}

\author{
Bankitbok Kharphuli* \\ M.Sc. Ag. (Agricultural Extension and Communication) \\ Syed H. Mazhar** \\ (Associate Professor), Department of Agricultural Extension and Communication, SHUATS (Prayagraj) \\ Dipak Kumar Bose $* * *$ \\ (Associate Professor), Department of Agricultural Extension and Communication, SHUATS (Prayagraj) \\ Jahanara**** \\ (Head and Associate Professor), Department of Agricultural Extension and Communication, SHUATS (Prayagraj) \\ *Author's email: bankitkharphuli06@gmail.com \\ DOI: 10.47856/ijaast.2021.v08i8.020
}

ABSTRACT: The present study was conducted to assess the knowledge of the ginger growers toward improved cultivation technology in Ri-Bhoi district of Meghalaya. A total number of 120 ginger growing farmers were selected proportionately from eight villages under Umsning Block because production, productivity and area under ginger cultivation were found to be maximum. The data were collected by personal interview method by using pre-tested interview schedule and later appropriate statistical analysis was done to find out the meaningful result. The findings of this study revealed that majority (65.83\%) of the respondents had medium level of overall knowledge towards improved cultivation technology of ginger followed by 21.67 percent and 12.50 per cent of the respondents with low and high levels of knowledge respectively.

KEYWORDS: Knowledge, Improved cultivation technology of ginger

\section{Introduction}

Ginger (Zingiber officinale Rosc.) is a flowering plant whose rhizome, ginger root or ginger, is widely used as a spice and a folk medicine. It belongs to the family Zingiberaceae. Its generic name Zingiber is derived from the Greek word zingiberis, which comes from the Sanskrit name of the spice, singabera, meaning shaped like a horn. Ginger offers a substantial protection from stroke and heart attack because of its ability to prevent blood clotting and also a 


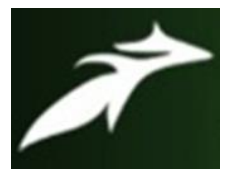

Bankitbok Kharphuli et al, International Journal of Advances in Agricultural Science and Technology, Vol.8 Issue.8, August-2021, pg. 183-188

ISSN: $2348-1358$

Impact Factor: 6.057

NAAS Rating: 3.77

multifaceted herb, crucial in the battle against cardiovascular diseases such as bowels, kidney diseases and respiratory diseases.

India is the leading producer of ginger in the world. Indian production is said to account for nearly half of the world's production, out of which around 10 per cent of the produce is exported to more than 50 countries. The crop occupies largest area in Orissa, followed by Karnataka, West Bengal, Kerala, Meghalaya, Mizoram and Sikkim.(Parthasarathy et al., 2008) India exports mainly in the form of whole and dry ginger. Indian dry ginger is known in the global market as 'Cochin Ginger and 'Calicut Ginger'. Cochin Ginger is considered as one of the best in the world.

Ginger is one of the important spice crops of the state of Meghalaya. Meghalaya is the third largest ginger producing state in India, producing 63.0 thousand MT (Spice Board 2016) and is cultivated in almost all the districts of Meghalaya. Ginger is considered as traditional crop of the state and it is said to have been cultivated since ancient times (Mawlong 2017). In Meghalaya, the Ri-Bhoi district ranks third in terms of ginger production, producing about 10500 metric tonnes of ginger from a land of 10574 hectares (2013-14) (Triparthi et al. 2008). Apart from improved varieties like Nadia, China, Varada, etc., a number of local cultivars exist in north eastern region. These varieties are high yielder of rhizomes as compared to standard cultivars like Nadia and Rio-De-Janeiro but have more fibre content.

Ginger cultivation in Meghalaya has been one of the most prominent crop cultivation practices in the Ri-Bhoi district. While this has been the case, the introduction and knowledge of new and improved methodologies and technologies has been one of the sectors which has not been properly defined in the State. This research is implemented in order to ascertain the rate and proper understanding of the knowledge level of the farmers in comparison with the recommended adoption practices disseminated by the State Agricultural Department for the improved production and productivity in order for the ginger growers to increase their profit from their produce.

\section{Research Methodology}

Descriptive research design was adopted for the study as it describes the characteristics or phenomena that are being studied. The present study was conducted in Ri-Bhoi district of Meghalaya. Out of 3 blocks in Ri-Bhoi district, Umsning block is selected purposively for the present study. From the selected block, eight villages namely, Kyrdem Kulai $5^{\text {th }}$ Mile, Kyrdem Kulai $6^{\text {th }}$ Mile, Pyllun, Mawpun Kshaid, Umiet, ICAR, Umtung and Nongsder were selected purposively where maximum number of farmers grows ginger. 


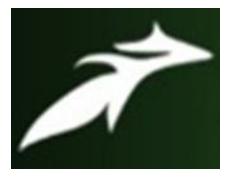

Bankitbok Kharphuli et al, International Journal of Advances in Agricultural Science and Technology, Vol.8 Issue.8, August-2021, pg. 183-188

ISSN: 2348-1358 Impact Factor: 6.057

NAAS Rating: 3.77

The primary data were collected with the help of interview schedule, which was prepared on the basis of the objectives of the study. The statistical tools like frequency, percentage, mean, standard deviation were used to interpret the data and for drawing the logical conclusion.

\section{Objectives of the study:}

1. To find out the socio-economic profile of the respondents.

2. To assess the knowledge of the respondents towards improved cultivation technology of ginger crop.

\section{Results and Discussion}

1. Socio-economic characteristics of the ginger growers

Table 1: Level of socio-economic profile characteristics of the ginger growers

\begin{tabular}{|c|l|c|c|}
\hline S. No & $\begin{array}{l}\text { Level of Socio-economic } \\
\text { characteristics of ginger } \\
\text { growers }\end{array}$ & Frequency & Percentage \\
\hline 1. & Low (7-18) & 38 & 31.66 \\
\hline 2. & Medium (19-37) & 73 & 60.83 \\
\hline 3. & High (38-54) & 9 & 7.51 \\
\hline & Total & 120 & 100 \\
\hline
\end{tabular}

From Table 1, it shows that majority i.e. 60.83 per cent of the respondents had medium level of socio-economic characteristics, 31.66 per cent had low level of socio-economic characteristics while only 7.51 per cent of the respondents had high level of socio-economic characteristics (Similar findings were also reported by Sharma et al., 2015)

\section{Knowledge level of ginger growers toward improved cultivation technology}

Table 2: Distribution of respondents based on the level of knowledge towards improved cultivation technology of ginger

\begin{tabular}{|c|l|c|c|c|c|c|c|}
\hline S. No & \multirow{2}{*}{ Statement } & \multicolumn{2}{|c|}{ Fully correct } & \multicolumn{2}{|c|}{ Partially correct } & \multicolumn{2}{c|}{ Not correct } \\
\cline { 3 - 8 } & & $\boldsymbol{f}$ & $\mathbf{\%}$ & $\boldsymbol{F}$ & $\boldsymbol{\%}$ & $\boldsymbol{f}$ & $\boldsymbol{\%}$ \\
\hline 1. & $\begin{array}{l}\text { Field preparation: 4-5 times } \\
\text { ploughing }\end{array}$ & 96 & 80.00 & 24 & 20.00 & 0 & 0 \\
\hline 2. & Soil: loamy is best suited & 97 & 80.83 & 23 & 19.17 & 0 & 0 \\
\hline
\end{tabular}




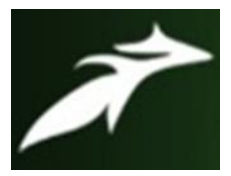

Bankitbok Kharphuli et al, International Journal of Advances in Agricultural Science and Technology, Vol.8 Issue.8, August-2021, pg. 183-188

ISSN: 2348-1358

Impact Factor: 6.057

NAAS Rating: 3.77

\begin{tabular}{|c|c|c|c|c|c|c|c|}
\hline 3. & Rain: moderate is preferable & 109 & 90.83 & 11 & 9.17 & 0 & 0 \\
\hline 4. & Variety: Nadia and Moran & 78 & 65.00 & 42 & 35.00 & 0 & 0 \\
\hline 5 . & $\begin{array}{l}\text { Sowing time: last } 15 \text { days of } \\
\text { April and first } 15 \text { days of } \\
\text { May }\end{array}$ & 118 & 98.33 & 2 & 1.67 & 0 & 0 \\
\hline 6. & $\begin{array}{l}\text { Spacing: } \\
\text { a. Row to Row }(30 \mathrm{~cm}) \\
\text { b. Plant to Plant }(20 \mathrm{~cm})\end{array}$ & 80 & 66.67 & 40 & 33.33 & 0 & 0 \\
\hline 7. & Mulching: paddy straw & 0 & 0 & 101 & 84.17 & 19 & 15.83 \\
\hline 8. & Alternate crops: ragi, paddy & 56 & 46.67 & 58 & 48.33 & 6 & 5.00 \\
\hline 9. & $\begin{array}{l}\text { Seed Rate (Rhizome): } 1500 \\
\mathrm{~kg} / \mathrm{ha}\end{array}$ & 16 & 13.33 & 97 & 80.83 & 7 & 5.83 \\
\hline 10. & FYM: 25 tonnes per ha & 77 & 64.17 & 37 & 30.83 & 6 & 5.00 \\
\hline 11. & $\mathrm{~N}: \mathrm{P}: \mathrm{K}-150: 50: 50$ & 0 & 0 & 118 & 98.33 & 2 & 1.67 \\
\hline 12. & Rhizome weight: $15-20$ gm & 70 & 58.33 & 50 & 41.67 & 0 & 0 \\
\hline 13. & Method of irrigation: sprinkler & 0 & 0 & 120 & 100 & 0 & 0 \\
\hline 14. & Irrigation: once in 6 to 8 days & 0 & 0 & 120 & 100 & 0 & 0 \\
\hline 15. & Weeding: 2 to 3 times & 104 & 86.67 & 16 & 13.33 & 0 & 0 \\
\hline 16. & Yield: $(15-20) \mathrm{t} / \mathrm{ha}$ & 16 & 13.33 & 104 & 86.67 & 0 & 0 \\
\hline 17. & $\begin{array}{l}\text { Method of harvesting: } \\
\text { Manually }\end{array}$ & 118 & 98.33 & 1 & 0.83 & 1 & 0.83 \\
\hline 18. & $\begin{array}{l}\text { Storage of rhizome: } \\
\text { Cowdung coated under } \\
\text { ground storage (rhizome } \\
\text { treated with quinalphos } \\
\text { and Mancozeb @ } 0.3 \% \text { for } \\
30 \text { mins) }\end{array}$ & 0 & 0 & 98 & 76.67 & 26 & 21.67 \\
\hline
\end{tabular}

f=Frequency, $\%=$ Percentage

From the above table 2, it shows that majority of the respondents had full knowledge about land preparation $(80.00 \%)$, soil type $(80.83 \%)$, improved varieties $(65.00 \%)$, sowing time $(98.33 \%)$, spacing $(66.67 \%)$, weeding (86.67\%) and method of harvesting $(98.33 \%)$. 


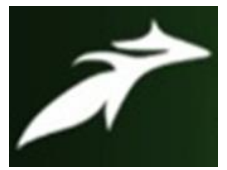

Bankitbok Kharphuli et al, International Journal of Advances in Agricultural Science and Technology, Vol.8 Issue.8, August-2021, pg. 183-188

ISSN: 2348-1358

Impact Factor: 6.057

NAAS Rating: 3.77

Figure 1: Distribution of the respondents based on the level of knowledge towards improved cultivation technology of ginger

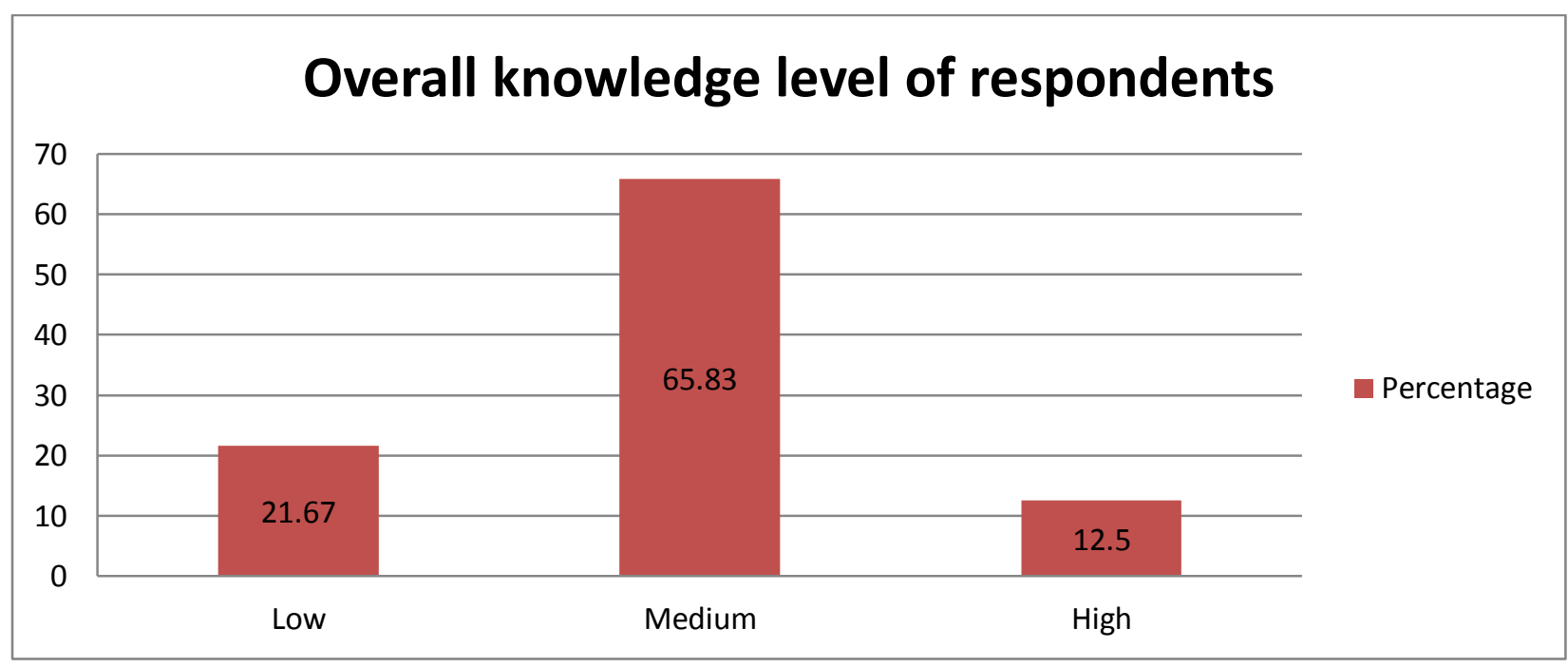

The results from Figure 1 revealed that majority, i.e., 65.83 per cent of the respondents had medium level of knowledge towards improved cultivation technology of ginger, 21.67 per cent of the respondents had low level of knowledge and remaining 12.5 per cent of the respondents had high level of knowledge (Similar findings were also reported by Jakkawad $\boldsymbol{e t}$ al., 2017)

\section{Conclusion}

It is concluded that majority of the respondents were having medium level of socioeconomic characteristics. In terms of overall knowledge towards improved production technology of ginger, majority of the respondents were having medium level of knowledge towards improved production technology of ginger. Thus, it can be concluded that in order for the ginger growers to increase the knowledge levels of the ginger growers, the State Department of Agriculture should make integrated extension efforts (trainings, demonstrations, field days, etc.) to provide the required technical knowledge in order to adopt the improved cultivation practices of ginger. Sustainability in agricultural production largely depends on proper development, conservation and use of natural resources at the micro level. Over the last few years, there have been many cases of rhizome diseases affecting the crop in many parts of ginger growing areas in Meghalaya. In the traditional agricultural system as well as in organic farming, managing rhizome diseases is a greater challenge to marginal and tribal farmers. Many farmers 


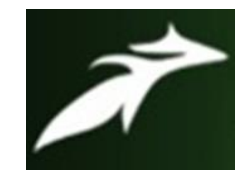

Bankitbok Kharphuli et al, International Journal of Advances in Agricultural Science and Technology, Vol.8 Issue.8, August-2021, pg. 183-188

ISSN: 2348-1358

Impact Factor: 6.057

NAAS Rating: 3.77

have given up ginger cultivation and others are still struggling to survive because of rhizome diseases and absence of income generating crops. These issues have to be addressed so that the productivity in the age-old traditional farming system could be sustained at optimum level.

\section{References}

[1]. Bheemudada, A.B. and Natikar, K.V (2016). A study on knowledge level of farmers about the ginger cultivation practices and constraints in adoption of improved practices, Journal of Farm Sciences Vol.29 No.1 pp.133-134.

[2]. Kumar, Ashok, Shukla, Gopal, Pala, Nazir, A.; and Chakravarty, Sumit (2015). Knowledge intensity and problem in ginger and large cardamom production technology of Lepcha tribes in Dzongu region of Sikkim, Innovative Horticulture: Concepts for Sustainable Development, Recent Trends, ISBN:978-9381274-85-9, , pp.- 37-40.

[3]. Kumar, Vikas, Sisodia, S.S. and Ranawat, Yogita (2017). Opinion of farmers toward improved ginger production technology in Udaipur district of Rajasthan, India, International Journal of Current Microbiology and Applied Sciences Vol 6 No. 9, pp 2207-2212

[4]. Mawlong M (2017). Ginger Cultivation in Umroi, Ri Bhoi District, Meghalaya. IOSR Journal Of Humanities And Social Science (IOSR-JHSS). 22(7): 36-45.

[5]. Rahman, H., Karuppaiyan, R., Kishore, K., and Denzongpa, R. (2008). Traditional practices of ginger cultivation in Northeast India. ICAR Research Complex for NEH Region, Sikkim, Indian Journal of Traditional Knowledge, Vol. 8(1), pp 23-28

[6]. Sheo, Govind, Chandra, Ram, Karibasappa, G. S., Sharma, C. K. and Singh, I. P. (1998). Spices in NEH Region, ICAR Research Complex for NEH Region, Umiam pp 9-22.

[7]. Tripathi, A.K., Datta, K.K., Khan, A.K., Verma, M.R. and Mandal, S. (2008). Economic assessment of front line demonstrations of ginger under mild tropical hill conditions of Meghalaya. In: Environment and Ecology 26(1A): 444-447.

[8]. Parthasarathy, V.A., Kandiannan, K. \& Rethinam, Ponniah. (2008). Spices and Condiments. Indian Institute of Spices Research (ICAR) Calicut. 